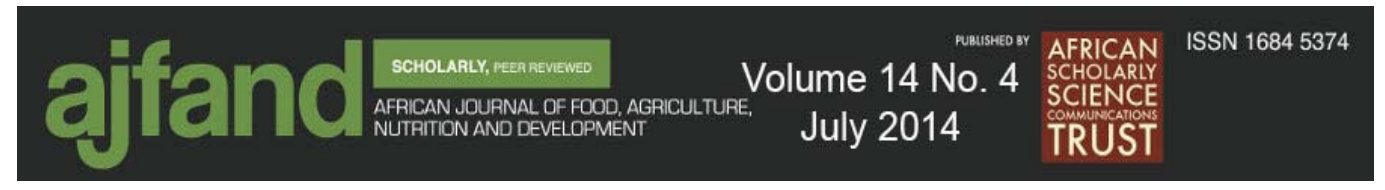

\title{
IMPROVING THE NUTRITIONAL STATUS OF MALNOURISHED CHILDREN USING SOYBEAN PRODUCTS IN RWANDA
}

\author{
Niyibituronsa $\mathrm{M}^{1^{*}}$, Kyallo $\mathrm{F}^{2}$, Mugo $\mathrm{C}^{2}$ and $S$ Gaidashova ${ }^{1}$
}

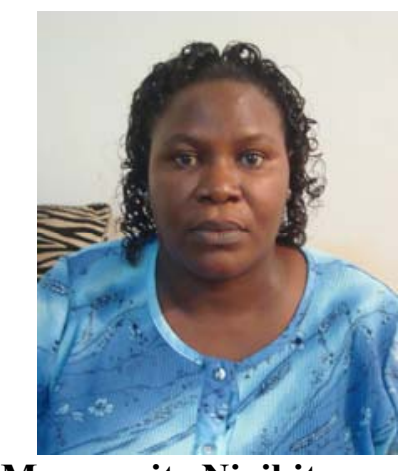

Marguerite Niyibituronsa

*Corresponding author email: niyibituronsam@gmail.com

${ }^{1}$ Rwanda Agriculture Board, P.O. Box 5016, Kigali, Rwanda

${ }^{2}$ Jomo Kenyatta University of Agriculture and Technology, P.O. Box 62000-00200, Nairobi, Kenya 


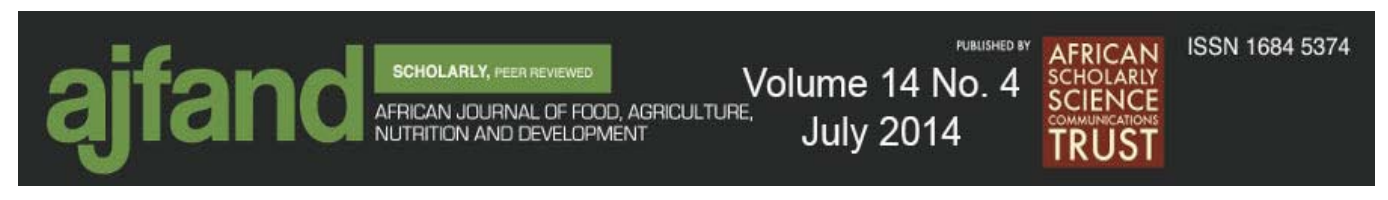

\section{ABSTRACT}

The prevalence of malnutrition is high in Rwanda especially in Ruhango District of Southern Province (23.5\% in 2009). The contribution of soybean (Glycine max L), which is an important source of high quality and inexpensive protein and oil, to improvement of nutritional status of malnourished children is unclear. Although a lot of research has been done on the production of soybean in Rwanda, research on soybean in the diet to improve the nutritional status of malnourished children has not been done. The aim of this study was to determine the effect of soybean flour and soybean milk on the nutritional status of malnourished children under the age of five. The objective was to determine the weight gain due to each treatment in comparison with the control group. This study was conducted in Ruhango District of Southern Province Rwanda. A survey was conducted where households growing and utilizing soybean were identified and anthropometric measurements were taken on 294 children to select malnourished children. Thirty malnourished children participate in the intervention which lasted three months. One cup $(250 \mathrm{ml})$ of soybean milk was supplemented to ten children per day. An equal number was supplemented with $25 \mathrm{~g}$ of soybean flour in soup $(250 \mathrm{ml})$. The caregivers of the ten children in the control group received nutrition education together with the two treatment groups. Anthropometric measurements were taken every month and entered in WHO ANTHRO software. Data was analyzed by regression models using GenStat $14^{\text {th }}$ edition and the magnitude of weight gain due to each of the treatments was predicted at $5 \%$ level of significance. A linear mixed model was used to estimate and compare weight gain among children fed on soybean milk and soybean flour supplement in comparison with the control group. Soybean products were found to affect weight gain of children $(\mathrm{P}=0.04)$. The mean weight gain was $0.9( \pm 0.5) \mathrm{kg}$ within three months of intervention. The difference in weight gain between the two treatment groups was not significant. To improve the nutritional status of malnourished children under five years further intervention is needed in terms of education and training on soybean based diet formulation.

Key words: soybean products, under five, Rwanda 


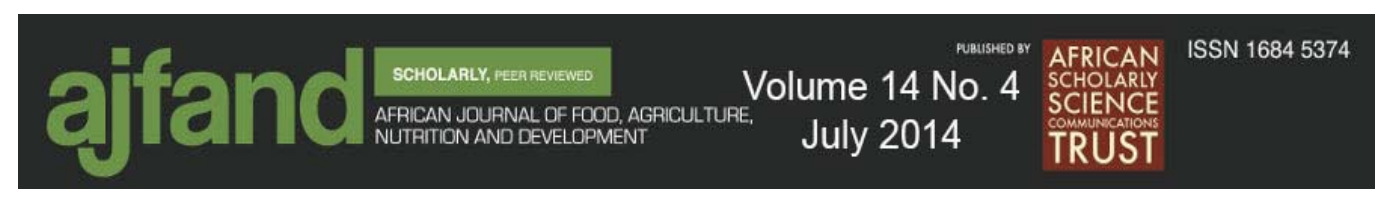

\section{INTRODUCTION}

The prevalence of malnutrition among children below the age of five in Southern Province, Rwanda, is high. In 2009, Ruhango District in the Southern Province of Rwanda had one of the highest prevalence of malnutrition at $23.5 \%$ according to Health Ministry Report, 2010 [1]. The Government of Rwanda, in its National Nutrition Policy, recognizes that adequate food and nutrition are a universal right and are essential for the physical, mental and emotional development of children as well as the quality of life for adults [2]. According to the Rwanda Ministry of health a combination of insufficient knowledge on appropriate feeding practices, poverty and the traditional monotonous food consumption practices based mainly on traditional grains, roots and tubers led to a persistent problem of malnutrition among the most vulnerable populations [2]. These are worsened by land scarcity where two percent of farming households do not own land, so they rent, share crops or borrow land [3].

Soybean (Glycine max L) is a legume that grows in tropical, subtropical, and temperate climates. Originally domesticated in China around 1700-1100 B.C., soybean is now cultivated throughout East and Southeast Asia where people depend on it for food, animal feed, and medicine [4].

Soybean reached Africa through missionaries in the early 19th century. At $38 \%$ soybean has the highest protein content of all food crops. Soybeans are regarded as equal in protein quality to animal foods [4]. In addition, compared to other proteinrich foods such as meat, fish, and eggs, soybean is by far the cheapest. The importance of soybeans and their products is primarily associated with their high nutritional quality especially with respect to protein and amino acids [5]. On a wet basis, soybeans contain about $35 \%$ protein, $17 \%$ oil, $31 \%$ carbohydrate and $4.4 \%$ ash [6]. According to the National Soybean Research Laboratory of Illinois in America, the high protein soybean milk and lactose free is a suitable low cost way of providing better nutrition and improved health. Soybean protein is the only vegetable with complete protein [7]. Soybean milk can be used to alleviate malnutrition as it has the same amount of protein like cow's milk (Table 1) [8].

In Rwanda research on the role of soybean in improving nutrition is needed since the prevalence of malnutrition is high $(23.5 \%$ in Ruhango district) and a lot of research was done on soybean cultivation to increase production (57089 Metric Tons in 2010 according to Rwanda Agriculture Board (RAB) stats). Area under cultivation of soybean, production and productivity (yield) has increased since 2004 in Rwanda [9]. It is in this perspective that this intervention was conducted to determine the extent to which soybean milk and soybean flour in the diet could improve the nutritional status of malnourished children under five. 


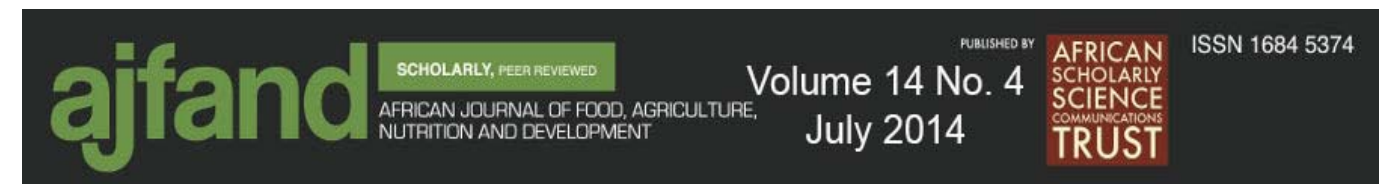

\section{MATERIALS AND METHODS}

\section{Survey \\ Sampling}

A multistage and stratified sampling technique was used to randomly select 294 households for inclusion in the survey. Ruhango district has 9 sectors and three were selected randomly: Byimana, Kinazi and Kinihira. Three cells from the three sectors were selected randomly. From Byimana sector, Muhororo was selected with two villages Mbuye and Remera, from Kinazi sector Burima was selected in Nyagahama and Nyarugenge villages, and Muyunzwe was selected from Kinihira sector in Muyunzwe and Nyamirambo villages.

Only households with children under five years were purposively selected with the help of community health workers and we got 294 households to participate in the survey. One child per household was considered for anthropometric measurements. Using WHO ANTHRO software thirty malnourished children who participated in the intervention were obtained from 294 children anthropometry data.

\section{The intervention study Preparation}

Four child feeders were trained to process soybean into milk to feed malnourished children in two villages Nyagahama and Nyarugenge at Burima-Kinazi. Two others were trained to make soybean sauce from roasted soybean flour to feed malnourished children in Mbuye and Remera villages at Muhororo-Byimana. In each of the households, a member responsible for the day to day care of the children was trained on soybean processing and utilization. Ten of the households were trained on soybean milk as well as nutrition education focusing on soybean milk. An equal number was trained on soybean flour and how to make a soup and nutritional education, while the control group received nutritional education only.

\section{Procedure for making soybean milk}

Soybean milk was prepared by cleaning whole soybeans by removing dirt and damaged soybeans. The soybeans were soaked into water in proportion of 1cup of soybean/4 cups of water for 8-12 hours; soybeans were then drained and rinsed with cold water. They were ground using a mortar and pestle and mixed with water 6 cups per one cup of soybeans and filtered through muslin cloth. Soymilk was boiled, and salt, sugar and flavors were added as desired [10]. The soybean milk was served cold. Previous studies/theory in CIALCA training guide on nutrition indicates that $120 \mathrm{~g}$ of soybean provide $1 \mathrm{~L}$ of soybean milk and residues can be cooked with vegetables [11]. From $1 \mathrm{~kg}$ of soybeans $8 \mathrm{~L}$ soymilk is extracted when a grinder is used [12].

\section{Procedure for making soy bean flour}

Soybean flour was made from roasted soybeans that were ground into a fine powder. The powder could be used to make soup. For a consistent soup one portion of soybean flour was mixed with 3 portions of water. Emphasis was also put on the procedures for preparing or making use of the processed products for the benefit of human health. 


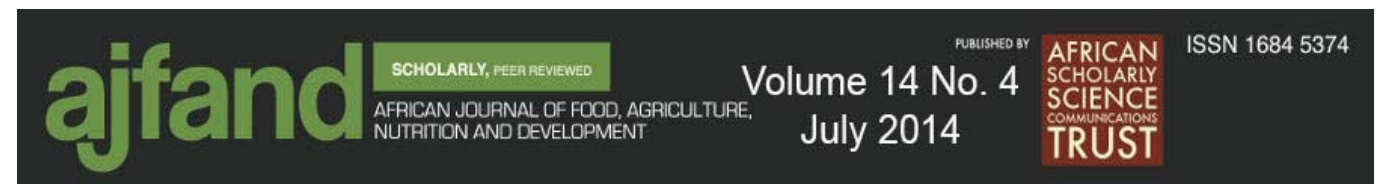

Soy flours were made to taste better and the most objectionable flavors were removed to improve the taste of the foods [13]

\section{Intervention procedures}

An intervention was conducted on 20 malnourished children to determine the effect of soymilk and soybean flour on their nutritional status in comparison with 10 malnourished children without soybean food consumption. The list of control group was provided to the health center for appropriate care. For the soybean milk treatment group, one cup (250ml) milk was supplied to 10 children once per day. For the soybean flour treatment group, $25 \mathrm{~g}$ in soup $(250 \mathrm{ml})$ was supplemented for the respective children. Therefore, around ten grams of protein and $125 \mathrm{Kcal}$ were supplemented with soybean milk and soybean soup treatments. The intervention took three months from 06 June to 6 September 2012. Measurement of weight, height and MUAC and record of food intake in household were done monthly in all sites including the control group at Muyunzwe. Children with chronic conditions were excluded from the intervention study.

The researcher in collaboration with child feeders monitored the intervention on a daily basis to ensure compliance with the set procedures by participating households.

\section{Data management and analysis}

Data collected from $6^{\text {th }}$ June to $6^{\text {th }}$ September 2012 was entered in Excel data base and WHO ANTHRO for anthropometric data. Analyses were done using WHO ANTHRO 2006 and GenStat $14^{\text {th }}$ edition 2011. To interpret the anthropometric data, the initial weights and heights taken during the survey were compared between clusters (Burima, Muhororo and Muyunzwe) to determine the uniformity of weights in all clusters before intervention. In addition, weights and height taken before were compared with the ones taken after the intervention to estimate the weight gain and height gain. The weights gain from three measurements was compared between clusters to evaluate the effect of treatments. A linear mixed model was used to estimate and compare weight gain among children fed on soybean milk and soybean flour supplement in comparison with the control group.

The differences between the two products were expected to cause variation in weight gain. In addition, the children under five years are different in ages which were also expected to cause variation in weight gain. In order to account for these potential sources of variation in weight gain, a mixed model of weight gain was fitted with product form and age as fixed effect and child as a random effect. The difference in weight gain due to any effects (soybean supplementation, age and child) was tested for statistical significance at 5\% significance level. Consequently, the magnitude of weight gain due to each of the effects was predicted. The equation below specifies the structure of the model that was fitted and the Table 2 show definition of variables. 


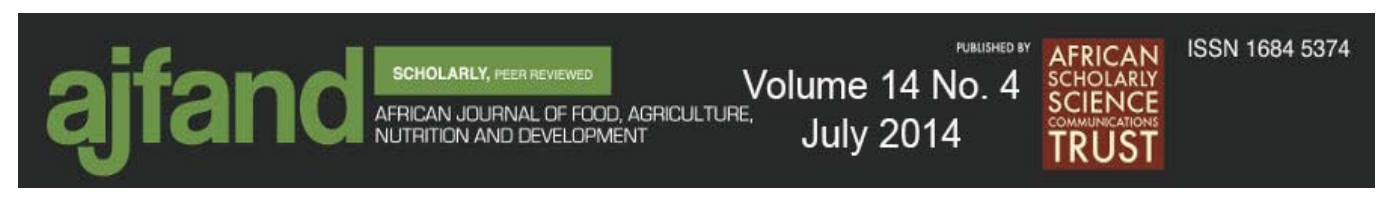

$\mathrm{Y}=\mu+\beta($ soybean products $)+\gamma($ age $)+\delta($ child $)+$ error

Where:

$\mathrm{Y}=$ Predicted mean weight gain of a child fed on soybean milk or soybean flour

$\mu=$ Overall mean weight gain due to soybean meal supplement

$\beta=$ coefficient of fixed effect, soybean product (Deviation from the overall mean due to soybean product effect)

$\gamma=$ coefficient of fixed effect age (Deviation from the overall mean due to age effect)

$\delta=$ coefficient of random effect child (Deviation from the overall mean due to child effect)

Error: unexplained variation

\section{Ethical considerations}

A consent form was signed by the mother/caregiver prior to beginning the intervention. This included the nature and purpose of the study, what would occur during the intervention, any risk, assures that all data collected would be coded to protect their identity and privacy, thus confidentiality was assured. In addition, members of the community were consulted in the planning of the research. Potential benefits to the community were articulated clearly and unambiguously. Research participants were considered partners, not research subjects. This was to ensure that members of the community such as health care workers and planners had ongoing oversight of the project $[16,17]$. Severely malnourished and sick children were transferred to the nearest hospital.

The research protocol was approved for implementation by the Rwanda National Ethical Committee (RNEC).

\section{RESULTS}

\section{Knowledge of production and usage pattern of soybean}

About two thirds $(63.6 \%)$ of the households in Ruhango District reported growing soybean. Soybean products were known by $89.5 \%$ of the households. Known products included soybean flour $86.1 \%$, soybean milk $69.4 \%$ and Tofu and oil $24.1 \%$. Utilization of soybean was reported by $68.4 \%$ of the households, with the most popular products being soybean flour $66.7 \%$, and soybean milk $10.9 \%$. Table 3 shows the number of households growing soybean and using soybean products. Among 107 households who did not grow soybean $44.8 \%$ used soybean products. Soybean can be bought from the market.

\section{Anthropometric measurements}

Figure 1 shows percentages of stunted (low height for age) children: $37.8 \%$, wasted (low weight for height): $3.1 \%$ and underweight (low weight for age): $8.5 \%$ among the 294 children measured during the survey in 2012. Ruhango District had improved a lot compared to the malnutrition situation in 2009 [1]. 

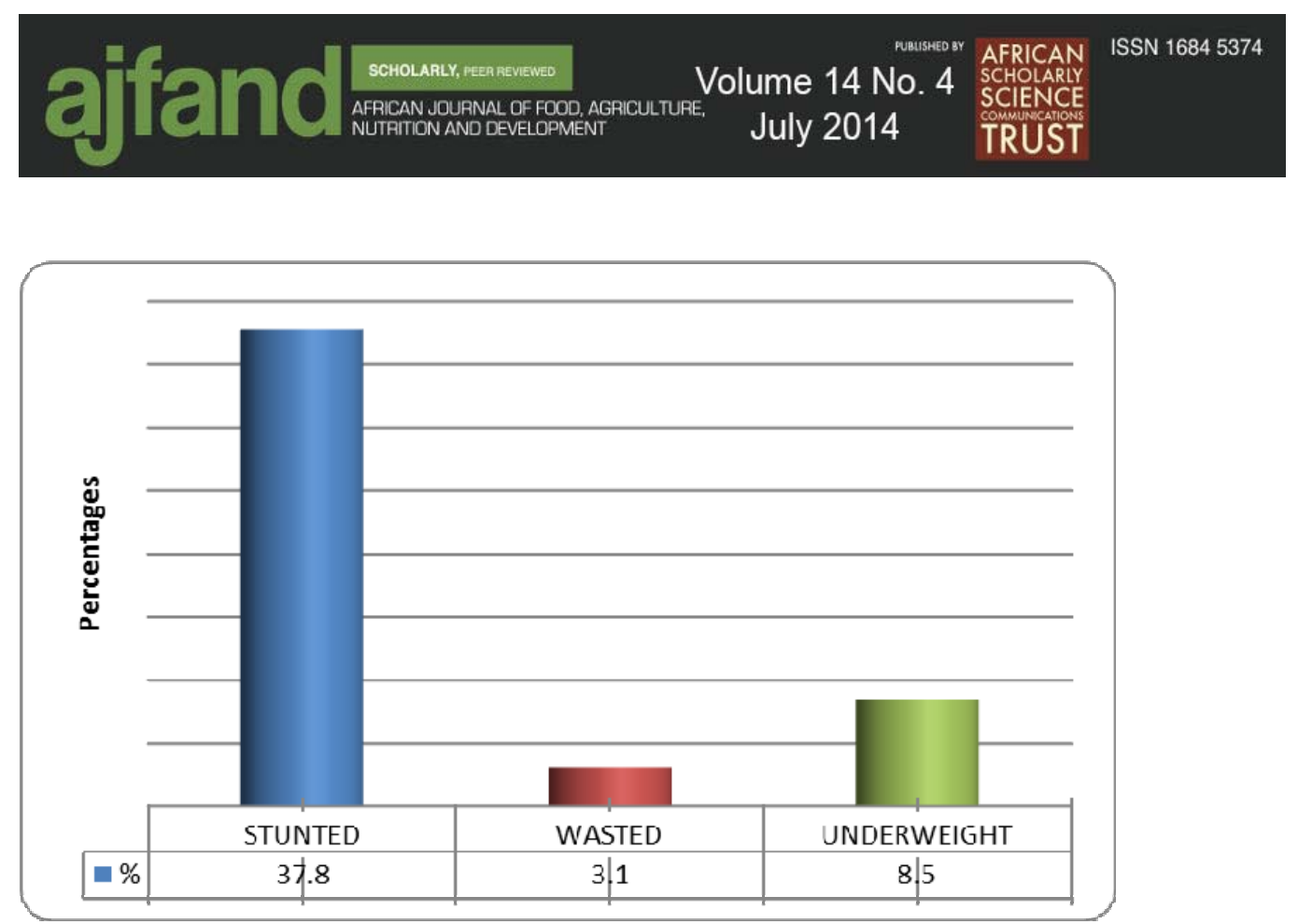

Figure 1: Chart of stunted, wasted and underweight children in Ruhango district

\section{The effect of soybean milk and soybean flour on the nutrition status of moderately malnourished children}

Anthropometric data taken before and after the intervention were compared between clusters for 30 children who finished the study. The initial weight and height taken before showed uniformity between clusters (Burima with soybean milk treatment, Muhororo with soybean soup treatment and Muyunzwe the control group). The weight and height increased after intervention as shown in Table 4.

Table 5 shows the weight gained by children between clusters. The mean weight gain with soybean milk treatment in Burima and soybean soup treatment in Muhororo were similar $(0.9 \mathrm{~kg})$. The control group children in Muyunzwe gained less weight than the two others $(0.3 \mathrm{~kg})$.

A linear mixed model was used to estimate and compare weight gain among children fed on soybean milk and soybean flour supplement in comparison with the control group using GenStat $14^{\text {th }}$ edition. The treatments were form in which the soybean was taken including the control. The first model to be fitted was $Y=\mu+\beta$ (soybean products)+ error

The effect of soybean products on weight of the children was tested at 0.05 level of significance. There was significant effect of soybean products treatment on the weight gain of children ( $F$ value 3.6, df 2 and $P$-value 0.04 )

The differences between the two products were expected to cause variation in weight gain but no difference in mean weight gain $(0.9 \mathrm{~kg})$. The children under five years are different in ages which were also expected to cause variation in weight gain. In order to account for these potential sources of variation in weight gain, a mixed model of 


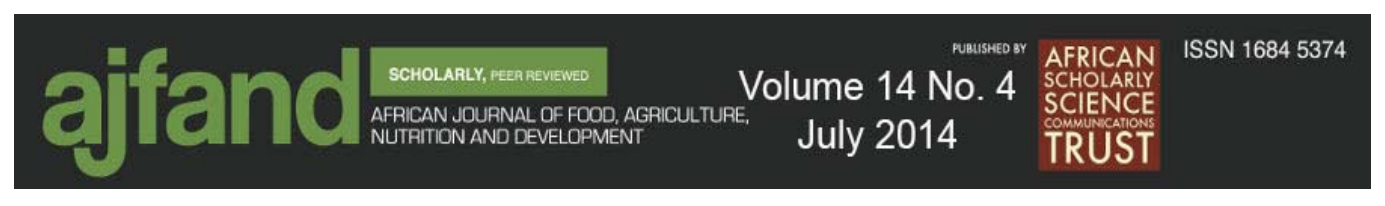

weight gain was fitted with product form and age as effects. $Y=\mu+\beta$ (soybean products $)+\gamma($ age $)+$ error

The weight gain due to soybean products and age of children as fixed effects was tested for statistical significance at 5\% significance level. There was no strong effect of age on weight gain of children during intervention with soybean products ( $\mathrm{F}$ value 0.8 , df 3 , P value 0.5 ).

The difference in weight gain due to soybean products, age and child as a random effect was tested for statistical significance at 5\% significance level. There was no random effect of child during intervention with soybean products. The first model fitted can be retained as the best one for this study. Advanced comparisons between treatments were done using Bonferroni multiple comparisons of means to test the statistical significance of means differences of weight gain between treatments in Table 6.

The means differences between all treatments were not statistically significant as the letter was the same (a). However, the means weight gain of children using soybean milk and soybean soup were high: $0.9( \pm 0.5) \mathrm{kg}$ for soybean milk treatment and 0.9 $( \pm 0.9) \mathrm{kg}$ for soybean soup against $0.3( \pm 0.2) \mathrm{kg}$ for the control group. Thus intervention with soybean milk and soybean soup had improved nutritional status of malnourished children.

FAO guidelines for measuring household and individual dietary diversity was used $[18,19]$. The food intake in the three groups during intervention were similar with average diversity score of 5.1 in Kinazi, 5.1 in Byimana and 5.2 for the control group in Muyunzwe which show that the effect can be accounted to soybean products.

\section{DISCUSSION}

Considering the cost of soybean at $500 \mathrm{~F}$ (Rwandan) per kg and meat at $2000 \mathrm{~F}$ per $\mathrm{kg}$, soybean can solve malnutrition problems as it is the cheapest among protein rich food such as meat, eggs and fish [4,7]. One $\mathrm{kg}$ of soybean give eight liters of milk, thus the cost of one liter is $63 \mathrm{~F}(500 / 8)$ while one liter of cow's milk costs $400 \mathrm{~F}$ and the protein content for the two kinds of milk are the same (Table 1) [8].

The study focused on soybean products as protein quality diet to improve nutritional status of malnourished children.

Soybean flour and soybean milk were used during the intervention on malnourished children in comparison with a control group to evaluate to what extend soybean products improve nutrition status. A linear mixed model was used to estimate and compare weight gain among children using GenStat and the results showed us the effect of soybean products on nutrition status of the children $(P=0.04)$. The differences between the two products were expected to cause variation in weight gain 


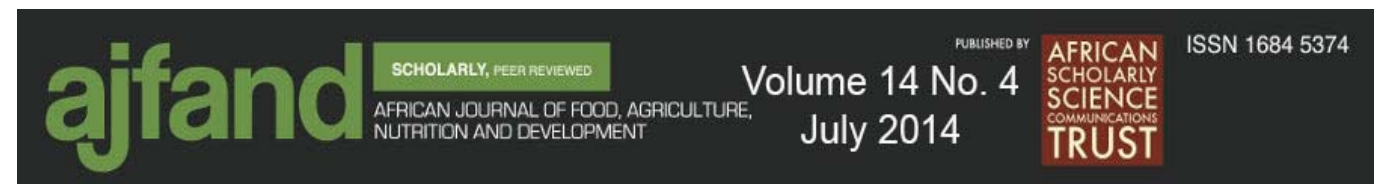

but Bonferroni multiple comparison tests showed that the average weight gain with soybean milk intervention was not significantly different from average weight gain with soybean flour soup intervention. Compared to a case study of short term intervention in four countries on infant food supplementation trial the average weight gain was reported as $0.8 \mathrm{~kg}$ in Rural Senegal, $1.1 \mathrm{~kg}$ in Congo Brazzaville, and $1.2 \mathrm{~kg}$ in Bolivia and New Caledonia which is similar to the one of this study $0.9 \mathrm{~kg}$ [14]. In Congo and New Caledonia the mean weight increment during the period of supplementation was high within the control group [14]. A study done in Malawi, a locally produced CSB++ was compared to both a locally produced soy ready-to-use supplementary food (RUSF) and an imported soy/whey RUSF for a group of children aged 6-59 months with Moderate Acute Malnutrition (MAM). Children who received $\mathrm{CSB}++$ gained slightly less weight than the children receiving the RUSFs [15]. Many intervention studies improved nutritional status of participants: In Colombia, an intervention study with whole powdered milk and commercial high-protein vegetable mix increased WAZ from -0.50 to +40 , In Indonesia 20 snacks of local foods containing bread, rice, wheat flour, sweet potato, coconut milk, cassava, potatoes, sugar, and oil providing $400 \mathrm{kcal} / \mathrm{d}$ on average with $5 \mathrm{~g} / \mathrm{d}$ protein in a day-care setting increased WAZ from -2.4 to +0.29 [20]. In Guatemala, findings show the effect of nutrition intervention with Atole (high energy and moderate protein drink) during the early childhood (before 3 years) on economic growth of adults. The increase was US\$0.67 per hour which meant a $46 \%$ increase in average wages [21].

\section{CONCLUSION}

This study was conducted to determine the effect of two soybean based products on malnourished children under five years in Ruhango district.

From the study only soybean flour, soybean milk and tofu were well known soybean products in Ruhango District. Soybean flour was mixed with vegetables and other foods. The intervention with soybean milk and soybean soup had improved nutritional status of malnourished children $(\mathrm{P}=0.04)$. The means weight gain of children using soybean milk and soybean soup was high: $0.9( \pm 0.5) \mathrm{kg}$ for soybean milk treatment and $0.9( \pm 0.9) \mathrm{kg}$ for soybean soup against $0.3( \pm 0.2) \mathrm{kg}$ for the control group. The treatments were form in which the soybean was taken. The difference in weight gain between the two treatment groups was not significant. Thus, Caregivers can choose the use of soybean milk or soybean soup in the diet of their children.

\section{RECOMMENDATIONS}

To improve the nutritional status of malnourished under-five children further intervention is needed in terms of education and training on soybean-based diet formulation.

\section{FUTURE RESEARCH}

More research should be done to increase the data base on soybean research in Rwanda and contribute to further development of improved products to combat 


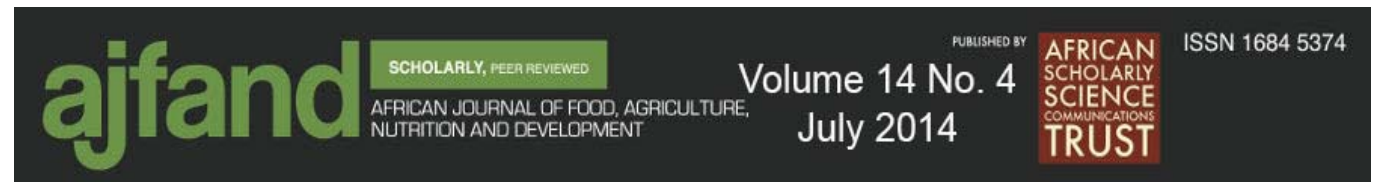

malnutrition. Time for future intervention should be extended (more than 3 months) to get more under fives who gain weight.

\section{ACKNOWLEDGEMENT}

The author of this paper wishes to acknowledge Regional Universities Forum for capacity building in agriculture (RUFORUM) who funded the study, Jomo Kenyatta University of Agriculture and Technology for knowledge provided, Rwanda Agriculture Board for material and moral support, and Association for Strengthening Agricultural Research in Central Africa (ASARECA) for training on scientific paper writing. 


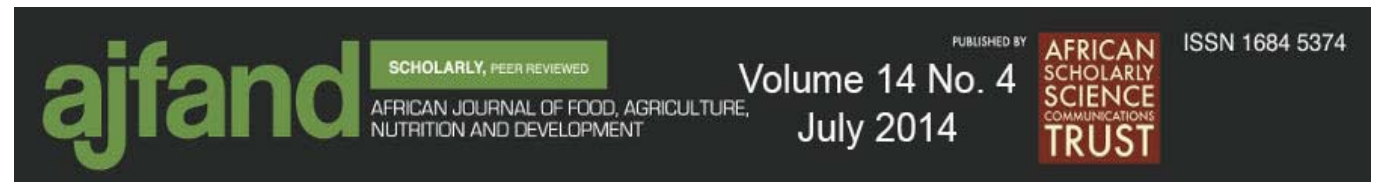

Table 1: Comparative Composition of Soymilk and Cow's Milk

\begin{tabular}{lll}
\hline & SOYMILK† $\%$ solids & COW'S MILK* \% Solids \\
\hline Protein & $3.5 \%$ & $3.5 \%$ \\
Carbohydrates & $2.3 \%$ & $4.9 \%$ \\
Fat & $2.4 \%$ & $3.5 \%$ \\
TOTAL & $8.2 \%$ & $11.9 \%$ \\
\hline
\end{tabular}

Source: World Initiative for Soy in Human Health, 2006, p3

$\dagger$ Approximate composition of plain, unsweetened, no oil-added aqueous extracted soya-base.

*Standardized whole milk 


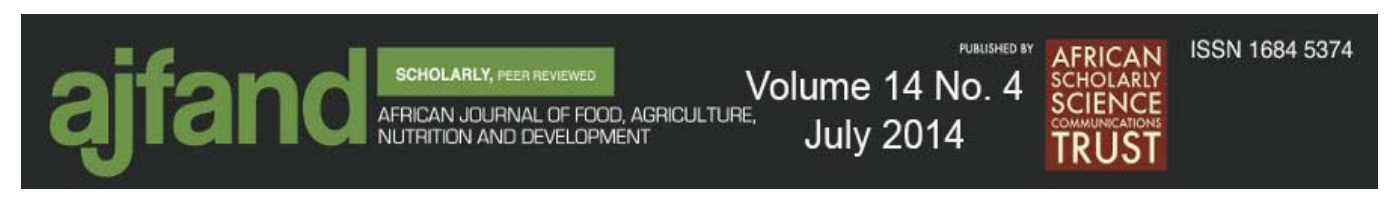

Table 2: Key variables and measurements

Variable

Dependent variable: Weight gain: Difference between the initial weight and the weight after 3 month of soya bean supplementation. Measurement was made in $\mathrm{Kg}$

Fixed factor: Soybean product Form in which the soybean was taken including the control was categorized at three levels $(1=$ soybean milk, $2=$ soybean flour, $3=$ control)

Fixed factor : Age

Random factor: child

\section{Definition and measurement}

Age of children taken from the survey and fixed at1, 2, 3, 4 , and 5 years for the intervention Each child has different capacity to respond to the intervention due to physical and biological differences 


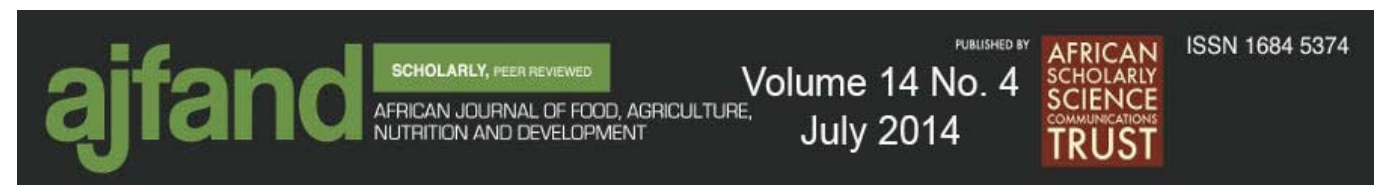

Table 3: Cross tabulation of soybean production and utilization

\begin{tabular}{|c|c|c|c|c|}
\hline & & \multicolumn{2}{|c|}{ USE SOY } & \multirow[t]{2}{*}{ Total } \\
\hline & & $\mathrm{NO}^{*}$ & YES** & \\
\hline \multirow[t]{2}{*}{ GROW SOY } & YES* & $11.56 \%$ & $52.04 \%$ & $63.60 \%$ \\
\hline & $\mathrm{NO}^{* *}$ & $20.06 \%$ & $16.32 \%$ & $36.39 \%$ \\
\hline Total & & $31.63 \%$ & $68.36 \%$ & $100 \%$ \\
\hline
\end{tabular}

\footnotetext{
*People who are not using soybean product they grow it for other purposes

**People who don't grow soybean use what they buy from the market
} 


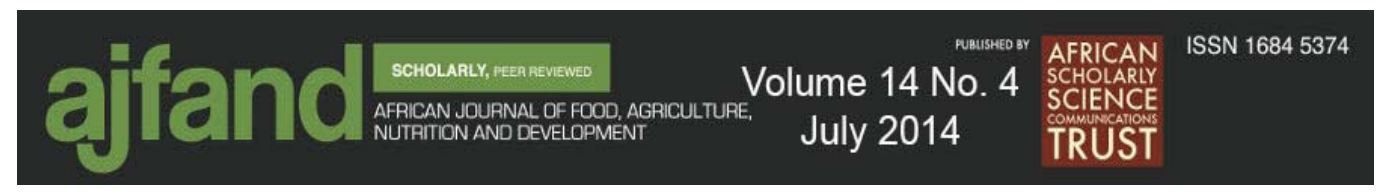

Table 4: Comparison of weight, height before and after the intervention

\begin{tabular}{lllll}
\hline Cluster & \multicolumn{2}{l}{ Before intervention } & \multicolumn{2}{l}{ After intervention } \\
& Weight $(\mathrm{kg})^{*}$ & Height $(\mathrm{cm})$ & Weight $(\mathrm{kg})^{* * *}$ & Height $(\mathrm{cm})$ \\
\cline { 2 - 5 } Burima & $10.8( \pm 1.5)$ & $85.0( \pm 9.1)$ & $11.7( \pm 1.6)$ & $88.8( \pm 8.8)$ \\
Muhororo & $11.0( \pm 1.6)$ & $84.2( \pm 7.6)$ & $12.0( \pm 1.6)$ & $87.4( \pm 6.8)$ \\
Muyunzwe & $11.0( \pm 1.8)$ & $85.6( \pm 8.9)$ & $11.3( \pm 1.8)$ & $86.2( \pm 9.5)$ \\
\hline
\end{tabular}

*The average weight of the children at the beginning of the intervention

**The average weight of the children after the intervention was used to calculate the weight gain. 


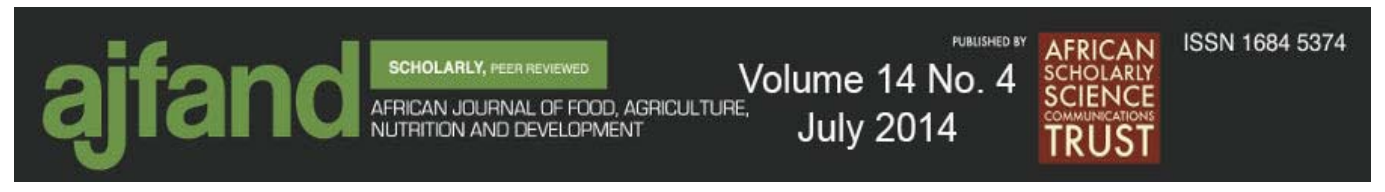

Table 5: Weight gain for three months

\begin{tabular}{llll}
\hline Cluster & Weight gain after & Weight gain after & Weight gain after \\
& $\mathbf{1}$ month $(\mathbf{k g}) *$ & $\mathbf{2}$ months $(\mathbf{k g}) *$ & $\mathbf{3}$ months $(\mathbf{k g}) *$ \\
\hline Burima & $0.63( \pm 0.6)$ & $0.81( \pm 0.5)$ & $0.92( \pm 0.5)$ \\
Muhororo & $0.65( \pm 0.8)$ & $0.84( \pm 0.9)$ & $0.92( \pm 0.9)$ \\
Muyunzwe & $0.15( \pm 0.1)$ & $0.18( \pm 0.2)$ & $0.27( \pm 0.2)$ \\
& & & \\
\hline
\end{tabular}

*The weight gain was calculated at the end of the month by subtracting the weight obtained with the initial weight, and by cluster to know the effect of each treatment 


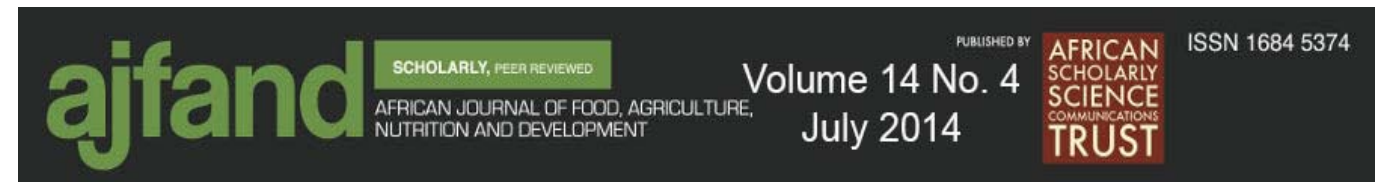

Table 6: Bonferroni test of statistical significance of means differences*

Treatments

\begin{tabular}{lll}
\hline & Mean weight gain $(\mathrm{kg})$ & \\
\hline 3 Control group & 0.27 & $\mathrm{a}$ \\
1 Treatment with soybean milk & 0.92 & $\mathrm{a}$ \\
2 Treatment with soybean soup & 0.92 & $\mathrm{a}$
\end{tabular}

$\bar{*}$ Bonferroni test of statistical significance of means differences is an advanced comparison of means, once the letter is the same there is no big difference and when the letters are different there is big difference between means 


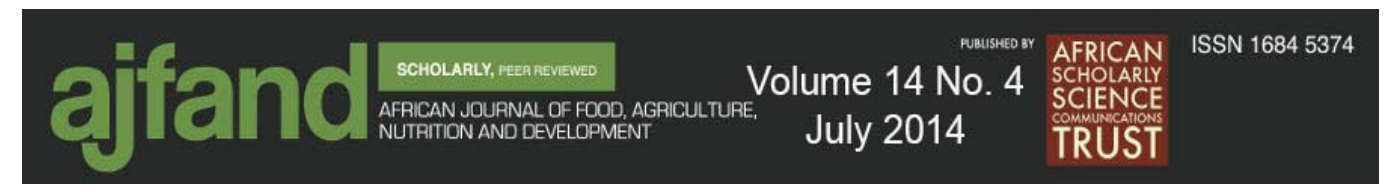

\section{REFERENCES}

1. Ministry of Health Rwanda. Annual report July 2009-June 2010. October 2010, p.128-134.

2. Ministry of Health. National Multi-sectoral Strategy to Eliminate Malnutrition in Rwanda. Action Plan for Implementation 2010 - 2013, June 2010, p.8-30.

3. Ministry of Finance and Economic Planning. The Government of Rwanda, Economic development and poverty reduction strategy. 2008-2012 draft (090707), July 2007, p.7.

4. World Healthier. Food Soybean protein, www.whf, $6^{\text {th }}$ September 2011.

5. Gandhi AP Quality of soybean and its food products. Central Institute of Agricultural Engineering, Bhopal-462038(MP), India, International Food Research Journal 2009;16: 11-19, .

6. Boye J and S Ribereau Assessing Compositional Differences in Soy Products and Impacts on Health Claims, Soybean and Nutrition, Prof. Hany El-Shemy (Ed.), ISBN: 978-953-307-536-5, 2011.

7. NSRL. The high protein soybean milk. www.nsrl, $6^{\text {th }}$ September 2011.

8. Ludvigsen HK Increasing the value of soy milk, Palsgaard Technical Paper, 2012, p.3

9. Kathiresan A Farm Land Use Consolidation in Rwanda: Assessment from the perspectives of agriculture sector. Ministry of Agriculture and Animal Resources, 6/29/2012, p3 and 18.

10. Hosken B Advances in soybean processing and utilization. University of Newcastle, method reviewed by Lui, KeShun. Soybeans: Chemistry, Technology and Utilisation, Aspen Pub Inc. Maryland, 1999.

11. Nyagaya M CIALCA training guide, Améliorer la santé à travers le soja. Un guide de formation de base. CIAT Afrique, 2008.

12. WISHH and Malnutrition Matters. Soymilk and Soy Dairy, Technology and Processing. May 2006, p3-7.

13. Kinney AJ Engineering Soybeans for Food and Health. Crop Genetics Research and Development, DuPont, Experimental Station, AgBioForum, 6(1\&2): 2003. 


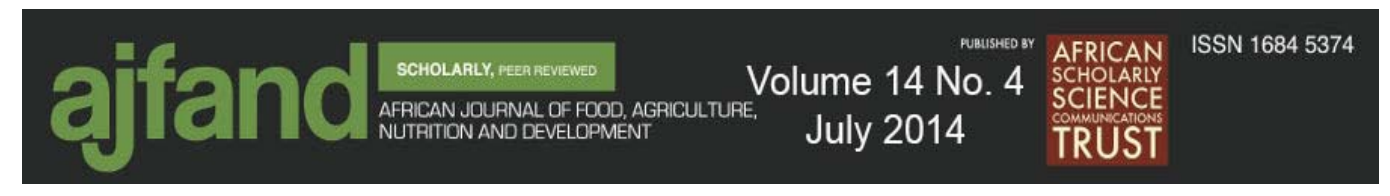

14. Simondon KB Anthropometric indicators for impact evaluation of food security programmes. Institut de Recherche pour le Développement, Montpellier, France, 2008, p 3-8.

15. LaGrone LN, Trehan I, Meuli GJ, Wang RJ, Thakwalakwa C, Maleta K and MJ Manary A novel fortified blended flour, corn-soy blend"plus plus",is not inferior to lipid-based ready-to-use supplementary foods for the treatment of moderate acute malnutrition in Malawian children. American Society for Nutrition, Am J Clin Nutr 2012; 95:212-9.

16. American Academy of Pediatrics Ethical policy.

http://www2.aap.org/sections/bioethics/policy.cfm. Accessed on $6^{\text {th }}$ September 2011.

17. World Health Organization Ethical considerations, http://www.who.int/ethics/research/en . Accessed on $6^{\text {th }}$ September 2011.

18. FAO Guidelines for measuring household and individual dietary diversity. 2011, ISBN 978-92-5-106749-9.

19. Swindale A and P Bilinsky Household Dietary Diversity Score (HDDS) for Measurement of Household Food Access. Indicator Guide, Version 2, 2006. http://www.fantaproject.org/focus/household.shtml Accessed on $6^{\text {th }}$ September 2011.

20. Caulfield $\mathbf{L} \mathbf{E}, \mathbf{H u f f m a n} \mathbf{S} \mathbf{L}$ and $\mathbf{E} \mathbf{G}$ Piwoz Interventions to improve intake of complementary foods by infants 6 to 12 months of age in developing countries: Impact on growth and on the prevalence of malnutrition and potential contribution to child survival. Food and Nutrition Bulletin, 1999; 20:2-186.

21. Hoddinott J, Maluccio J A, Behrman J R, Flores R and R Martorell Effect of a nutrition intervention during early childhood on economic productivity in Guatemalan adults. Lancet 2008; 371: 411-16. 